\title{
Adaptive Response of HK-2 Cells to High Levels of COM Crystals Highlights CaSR as an Enhancer of Crystal Adhesion
}

\author{
Siyu Chen \\ Lanzhou University Second Hospital \\ Junsheng Bao \\ Lanzhou University Second Hospital \\ Jianzhong Lu \\ Lanzhou University Second Hospital \\ Zhongyun Ning \\ Lanzhou University Second Hospital

\section{Zhongjin Yue} \\ Lanzhou University Second Hospital \\ Xiaoran Li ( $\sim$ lixiaoran05@163.com ) \\ Institute of Urology
}

\section{Research}

Keywords: urinary calculus, calcium-sensing receptor, phosphatidylserine, reactive oxygen species, crystal adhesion

Posted Date: September 28th, 2020

DOI: https://doi.org/10.21203/rs.3.rs-76977/v1

License: @ (1) This work is licensed under a Creative Commons Attribution 4.0 International License. Read Full License 


\section{Abstract}

Background: Calcium oxalate monohydrate (COM) is an aetiologic factor for urolithiasis. However, how Human Kidney-2 (HK-2) cells respond to a high COM has not yet been completely elucidated.

Materials and methods: A gel-based proteomics approach was applied to investigate COM-induced cellular proteomic changes. The COM-induced upregulation of calcium-sensing receptor (CaSR) in HK-2 cells was studied. Surface phospholipids (PS), which play a role in urolithiasis formation by mediating adhesion of HK-2 cells, were labelled in the inner or outer leaflet of the plasma membrane of HK-2 cells with fluorescent nitrobenzoxadiazole (NBD) to form NBD-PS to detect transmembrane movements of PS. After labelling, HK2 cells were exposed to $\mathrm{COM}$ in the presence of the CaSR-specific agonist gadolinium chloride $\left(\mathrm{GdCl}_{3}\right)$ or the CaSR-specific antagonist NPS2390. Inward and outward transmembrane movements of PS were tracked with a fluorescence quenching assay. Surfaceexpressed PS was detected by an annexin V binding assay. Changes in aminophospholipid translocase (APLT), oxidative stress (OS), levels of apoptosis-related proteins in HK-2 cells and crystal adhesion were also assessed.

Results: COM increased CaSR and surface-expressed PS levels, decreased APLT activity, impaired inward transport of PS, and enhanced outward transport of PS. However, pretreatment with $\mathrm{GdCl}_{3}$ further effectively inhibited the inward movement of PS and APLT activity and increased surface-expressed PS levels compared with COM treatment alone. In contrast, NPS2390 promoted the inward movement of PS and APLT activity and decreased surface-expressed PS levels compared with COM treatment alone. COM increased OS, apoptosis of HK-2 cells and crystal adhesion onto cells, and this increase was further enhanced by $\mathrm{GdCl}_{3} \mathrm{pretreatment}$ but attenuated by NPS2390 treatment.

Conclusions: These results strongly suggest that COM-induced CaSR generation may affect crystal adhesion by regulating PS externalization, apoptosis and OS in HK-2 cells.

\section{Background}

Urolithiasis is mainly formed by calcium oxalate $(\mathrm{CaOx})$ and is often associated with potential metabolic disorders such as hypercalciuria, hyperoxaluria and hypocitraturia[1]. The formation of $\mathrm{CaOx}$ stones usually begins with nucleation, growth and aggregation of crystals. In addition, adhesion of $\mathrm{CaOx}$ crystals to renal tubular epithelial cells is critical.

Studies of the genesis of kidney stones based on intracellular $\mathrm{CaOx}$ levels have found that $\mathrm{CaOx}$ monohydrate (COM) crystals and/or oxalates can adhere directly to living tubular epithelial cells under appropriate conditions[2, 3]. Because of the nature of the crystal binding sites on the top surfaces of cells, the plasma membrane promotes their adhesion[4], but the mechanism remains unclear. The COM-induced presence of high levels of surface phospholipid (PS) in the extracellular leaflets of the renal epithelial cell membrane may contribute to the retention of COM crystals on the cell surface[5, 6]. However, to the best of our knowledge, the mechanism by which COM promotes the collapse of renal epithelial membrane phospholipid asymmetry is unclear.

In all mammalian cell types studied thus far, the 2 leaflets of the plasma membrane bilayer have an asymmetrical phospholipid distribution. PSs, aminophospholipids and most phosphatidylethanolamines are concentrated in the cytoplasmic (inner) leaflet, while choline phospholipids, phosphatidylcholines and sphingomyelins are predominantly located in the exoplasmic (outer) leaflet[7]. This asymmetrical distribution of phospholipids is established and maintained by membrane proteins, which transport phospholipids between the cytoplasmic and exoplasmic leaflets.

Three types of phospholipid transporters have been identified to play roles in the regulation of membrane lipid sidedness. First, ATPdependent aminophospholipid translocase (APLT), also known as flippase, mediates the localization of PS and phosphatidylethanolamine in the inner leaflet by rapidly transporting these substances from the outer to the inner leaflet of the plasma membrane against their respective concentration gradients. Second, the ATP-dependent phospholipid floppase slowly moves phospholipids from the inner to the outer leaflet. In addition to these 2 ATP-requiring transporters, the ATP-independent, $\mathrm{Ca}^{2+}$ dependent scramblase randomly transports all phospholipids bidirectionally. Phospholipid asymmetry in biological membranes is maintained by the activity of the first 2 transporters and by scramblase inactivation[8, 9].

However, during the formation of kidney stones, multiple molecules and active proteins participate in complex interactions between COM crystals and renal epithelial cells. Most previous studies have focused only on one or two genes or proteins with varying results, so understanding of the changes in protein expression that occur after oxalate and/or COM exposure and how they participate in stone 
formation is limited. In addition to the proteins that have been studied, we hypothesize that other candidate proteins may also be involved in regulating the asymmetric distribution of phospholipids and the formation of renal stones in renal epithelial cells.

In our study, we investigated global protein changes in HK-2 cells exposed to a high-COM environment using a gel-based proteomics approach followed by protein analysis. A total of 11 proteins were detected, and 10 proteins, including calcium-sensing receptor (CaSR), were identified as differentially expressed proteins. It has been reported that CaSR increases CaOx crystal adhesion[10], and extracellular PS may promote the adhesion of crystals on the cell surface of renal epithelial cells. Therefore, we selected CaSR for further study and hypothesized that this protein alters the distribution of PS by affecting the activity of APLT, resulting in adhesion of COM on renal epithelial cells. Since the phospholipid transporters catalyse unidirectional or bidirectional transport of lipids from one membrane leaflet to the other, we monitored the inward and outward movement of PS. The exposure of phosphatidylserine (PS) on the outer plasma membrane is a unique feature of apoptotic cells. Together with other "eat me" signals, phosphatidylserine exposure enables the recognition and phagocytosis of dying cells (efferocytosis), helping to explain the immunologically silent nature of apoptosis[11, 12].Since apoptosis is a common mechanism underlying the pathophysiology of urolithiasis, we also evaluated it in our study.

$\mathrm{CaOx}$ crystals lead to the activation of NADPH oxidase (NOX), production of ROS and increased expression of molecules such as osteopontin and monocyte chemoattractant protein-1 $[13,14]$. Because the injurious effects of COM on renal cells are caused by ROS and oxidative stress (OS) production[15, 16], we also evaluated whether ROS and OS are regulated by $\mathrm{CaSR}_{\text {. GdCl }}$ (a specific CaSR activator) and NPS2390 (a specific CaSR antagonist) were used to evaluate the involvement of CaSR in adhesion of COM on renal epithelial cells and to explore the possible underlying mechanism.

\section{Methods}

\section{Preparation of COM crystals}

We prepared crystals as described previously[17]. COM crystals formed immediately as we mixed equal volumes of $10 \mathrm{mM} \mathrm{CaCl}_{2}$ and $10 \mathrm{mM}$ sodium oxalate at approximately $26^{\circ} \mathrm{C}$ and after approximately 3 days at $4^{\circ} \mathrm{C}$. Deionized water was used to wash the COM, which was then dried at $62^{\circ} \mathrm{C}$. Fourier transform infrared spectroscopy was used to confirm that the crystals were COM. A stock solution was created with $5 \mathrm{mg} / \mathrm{ml} \mathrm{COM}$ in sterile phosphate-buffered saline (PBS). The COM was evenly distributed in a monolayer $\left(67 \mu \mathrm{g}\right.$ of crystals $/ \mathrm{cm}^{2}$ of cells) and settled on the cells under the force of gravity. PBS was added to ensure that the volume was the same for each group.

\section{Cell culture}

Human kidney epithelial cells (HK-2 cells) were maintained in culture in Dulbecco's modified Eagle's medium (DMEM) supplemented with $1 \%$ antibiotics and $10 \%$ foetal bovine serum (FBS) in a humidified atmosphere of $95 \% \mathrm{O}_{2} / 5 \% \mathrm{CO}_{2}$ at $37^{\circ} \mathrm{C}$.

\section{Protein extraction, two-dimensional gel electrophoresis (2-DE) and staining}

After cultivating HK-2 cells with or without COM ( $67 \mu \mathrm{g}$ of crystals $/ \mathrm{cm}^{2}$ of cells) for $24 \mathrm{~h}$, we harvested the cells into tubes containing $0.5 \mathrm{M}$ EDTA in PBS and incubated at $4^{\circ} \mathrm{C}$ for 30 min before removing the adherent crystals. Then, the cells were washed with PBS to remove EDTA, resuspended in lysis buffer, and incubated at $4^{\circ} \mathrm{C}$ for $30 \mathrm{~min}$. The suspensions were then centrifuged to remove insoluble debris and particulate matter.

A total of $200 \mathrm{mg}$ of protein derived from each sample was mixed with a rehydration buffer (8 M urea, 2\% CHAPS, $18 \mathrm{mM}$ DTT, $0.5 \%$ IPG buffer, trace bromophenol blue) to obtain a final volume of $200 \mathrm{ml}$ per sample. The samples were then rehydrated onto individual Immobiline DryStrips (7 cm long, nonlinear pH gradient of 3-10; GE Healthcare, Uppsala, Sweden) for $16 \mathrm{~h}$ at room temperature. Isoelectric focusing (IEF) was performed at $500 \mathrm{~V}$ for $1 \mathrm{~h}, 1,000 \mathrm{~V}$ for $1 \mathrm{~h}$, and 8,000 $\mathrm{V}$ for $10 \mathrm{~h}$ to reach a total of approximately $60-80$ $\mathrm{kVh}$. After IEF, the strips were placed in an equilibration buffer (130 mM DTT, $112 \mathrm{mM}$ Tris-base, $6 \mathrm{M}$ urea, 30\% glycerol, $4 \%$ SDS, and $0.002 \%$ bromophenol blue) for $20 \mathrm{~min}$ and then incubated with a similar buffer (in which $130 \mathrm{mM}$ DTT was replaced with $135 \mathrm{mM}$ iodoacetamide) for $20 \mathrm{~min}$. The proteins on the equilibrated strips were further separated on $12.5 \%$ polyacrylamide gels at $120 \mathrm{~V}$ for approximately $1.5 \mathrm{~h}$. The proteins were detected by a modified silver-staining method compatible with MS analysis. 
We analysed differences in protein levels among samples with Image Master software. Following spot detection, a matched set including all three batches of gels was built. A reference gel was selected from the control gels, and unmatched spots were added to the reference gel. Normalization was based on the total spot density.

We excised differentially expressed protein spots from the preparative gels, destained them and digested them overnight. For protein identification, a Finnigan LTQ mass spectrometer coupled with a Surveyor HPLC system (ThermoQuest) was used to analyse the extracted peptides. Briefly, we separated the protein digests with Microcore RP columns (C18 0.15 mm*150 mm; ThermoHypersil, San Jose, CA, USA). Solvent A was $0.1 \% \mathrm{v} / \mathrm{v}$ formic acid, and solvent B was $0.1 \% \mathrm{v} / \mathrm{v}$ formic acid in $100 \% \mathrm{v} / \mathrm{v}$ acetonitrile (can). The gradient was held at $2 \%$ solvent B for 20 min and increased linearly to $98 \%$ solvent B in $1.5 \mathrm{~h}$. The peptides were eluted from C18 microcapillary columns (120 $\mu \mathrm{l}$ per $\mathrm{min}$ ) and electrosprayed directly into an LCQ-Deca mass spectrometer (with a spray voltage of 3.0 $\mathrm{kV}$ and a capillary temperature of $180^{\circ} \mathrm{C}$ ). The full scan ranged from $\mathrm{M} / \mathrm{Z} 400$ to 2,000. Protein identification using the MS/MS raw data was performed with SEQUEST software based on the Swiss-Prot database. Both $y$ ions and $b$ ions were included in the database search. The results of protein identification were filtered by the DelCn $(\geq 0.1)$ and Xcorr $(1+\geq 1.9,2+\geq 2.2,3+\geq 3.75)$ values. The NCBI and ExPASy protein databases were used to determine the main functions of all the identified proteins.

\section{Annexin V binding analysis}

A FITC-labelled annexin V staining assay was used to measure the PS exposure of HK-2 cells. Cells were seeded in 6-well plates, grown to approximately $80 \%$ confluence ( $67 \mu \mathrm{g}$ of crystals $/ \mathrm{cm}^{2}$ of cells) and treated with COM crystals with or without the CaSR activator $\mathrm{GdCl}_{3}(300 \mu \mathrm{M})$ for $30 \mathrm{~min}$ or the CaSR inhibitor NPS2390 $(10 \mu \mathrm{M})$ for $60 \mathrm{~min}$. After the reaction, the cells were harvested and labelled with annexin V-FITC in Annexin V binding buffer (BD Pharmingen ${ }^{\mathrm{TM}}$ ). We used a FACSAria ${ }^{\mathrm{TM}}$ flow cytometer with an excitation wavelength of $488 \mathrm{~nm}$ and an emission wavelength of $530 \mathrm{~nm}$ to evaluate the annexin $V$ fluorescence of the cells after $15 \mathrm{~min}$ of incubation in the dark. The percentage of annexin V-positive cells was used to measure PS exposure.

\section{Measurement of MDA, LDH, and SOD levels}

The levels of MDA, SOD, and LDH were measured using a commercial kit according to the manufacturer's instructions.

\section{HK-2 cell labelling with nitrobenzoxadiazole (NBD)-labelled PS (NBD-PS)}

PS transmembrane bidirectional movement was observed with NBD-PS (Avanti® Polar Lipids), a fluorescent analogue of phosphatidylserine. NBD-PS dissolved in chloroform was dried under nitrogen and solubilized in absolute ethanol $\left(6 \mathrm{nmol}\right.$ for $2 \times 10^{7}$ cells). We labelled 2 groups of cells. In one group, called group A, we inserted NBD-PS into the outer plasma membrane[18, 19]; in the other group, group B, we inserted NBD-PS into the inner plasma membrane. We prevented internal movement in group A by cooling the cells to $2^{\circ} \mathrm{C}$. Then, an ethanolic solution of NBD-PS was added to a suitable volume of cell suspension (approximately $2 \times 10^{7}$ cells per $\mathrm{ml}$ ) in mPBS, and the mixture was vortexed. Non-inserted NBD-PS was removed by washing the cells with ice-cold mPBS after incubation on ice for $15 \mathrm{~min}$. The group B cell suspensions were incubated with NBD-PS in $\mathrm{mPBS}$ at $37^{\circ} \mathrm{C}$ for $1 \mathrm{~h}$ with $5 \mathrm{mM}$ diisopropyl fluorophosphate (Sigma-Aldrich) to prevent NBD-PS degradation. Redistribution of NBD-PS to the cytoplasmic membrane leaflet was mediated by APLT, which mediates the localization of PS and phosphatidylethanolamine to the inner leaflet of the plasma membrane by rapidly transporting these substances from the outer to the inner leaflet. Any NBD-PS remaining in the outer leaflet was removed by washing the cells 3 times with mPBS containing BSA $(1 \% \mathrm{w} / \mathrm{v})$.

\section{Fluorescence quenching and PS translocation analysis}

McIntyre and Sleight used dithionite to quench the fluorescence of superficial NBD-PS. To use a similar approach, we first incubated cells with NBD-PS-labelled outer leaflets in mPBS with $5 \mathrm{mM}$ diisopropyl fluorophosphate to evaluate PS inward movement. NBD-PS inward transmembrane movement was initiated by incubating the cells with prewarmed mPBS containing COM crystals (67 $\mu \mathrm{g}$ of crystals $/ \mathrm{cm}^{2}$ of cells $)$ and the CaSR activator $\mathrm{GdCl}_{3}(300 \mu \mathrm{M}, 30 \mathrm{~min})$ or the CaSR inhibitor NPS2390 $(10 \mu \mathrm{M}, 1 \mathrm{~h})$ at $37^{\circ} \mathrm{C}$. Every 10 min, we removed aliquots of the cell suspension and then measured the fluorescence intensity with an RF-5000 spectrofluorophotometer (Shimadzu, Kyoto, Japan) at a wavelength of $530 \mathrm{~nm}$ with a $10 \mathrm{~nm}$ slit width and an excitation wavelength of $470 \mathrm{~nm}$ with a $5 \mathrm{~nm}$ slit width. The average fluorescence (FT) during the first 50 seconds was recorded. Dithionite was then added from a stock solution of $1 \mathrm{M}$ sodium dithionite freshly dissolved in $1 \mathrm{M}$ Tris $(\mathrm{pH} 10)$ to a final concentration of $25 \mathrm{mM}$ to quench NBD fluorescence on the cell surface. The average fluorescence intensity decrease (FD) over a period of 240 seconds was recorded. The cell membrane was permeabilized with $1 \%(\mathrm{w} / \mathrm{v})$ Triton X-100, the NBD fluorescence of the inner leaflet of the membrane was quenched 
with dithionite, and the fluorescence intensity was recorded for 50 seconds (F0). The inner leaflet percentage was calculated with the following formula: inner leaflet percentage $=100[(\mathrm{FD}-\mathrm{F0}) /(\mathrm{FT}-\mathrm{F0})]$. Cells with NBD-PS-labelled inner leaflets were incubated in mPBS containing $1 \%$ BSA with COM crystals ( $67 \mu \mathrm{g}$ of crystals $/ \mathrm{cm}^{2}$ of cells) or with COM and $\mathrm{GdCl}_{3}$ or NPS2390 to evaluate PS outward movement. Every $10 \mathrm{~min}$, we removed aliquots of the cell suspension and calculated the outer leaflet percentage with the following equation: outer leaflet percentage $=100[(\mathrm{FT}-\mathrm{FD}) /(\mathrm{FT}-\mathrm{F} 0)]$.

\section{Western blot analysis}

We prepared total proteins according to the kit manufacturer's instructions. A Bradford protein assay was performed to determine the supernatant protein concentration with BSA as the reference standard. We blotted all of the proteins $(20 \mu \mathrm{g})$ onto a nitrocellulose membrane in transfer buffer at $100 \mathrm{~V}$ for $1 \mathrm{~h}$ in a water-cooled apparatus after electrophoresis in Tris-glycine electrophoresis buffer with standard $10 \%$ SDS-PAGE. The membrane was blocked in TBS-T buffer with $5 \%$ skimmed milk at $37^{\circ} \mathrm{C}$ for $1 \mathrm{~h}$ and then incubated overnight at $4^{\circ} \mathrm{C}$ with anti-CaSR antibodies (1:2,500), APLT antibodies (1:1,500), and antibodies against SOD, NOX, Bcl-2, Bax, procaspase-9, caspase-9, pro-caspase-8, cleaved-caspase-8, cleaved-caspase-3 and cytochrome C. TBS-T was used to wash the membrane 3 times. The membrane was then incubated with alkaline phosphatase-conjugated anti-lgG antibodies diluted 1:1,000 in TBS-T for $1 \mathrm{~h}$ at room temperature. Western Blue Stabilized Substrate for Alkaline Phosphatase was used to detect antibody-antigen complexes. A Bio-Rad ChemiDoc ${ }^{\mathrm{TM}} \mathrm{EQ}$ densitometer and Bio-Rad Quantity One software were used to evaluate the protein band densities.

\section{Crystal adhesion assay.}

One of the methods used before was performed to carry out crystal adhesion experiments[20]. The cells were randomly divided into 4 groups after culture for 24 hours: (1) control group: cells were cultured in DMEM at $37^{\circ} \mathrm{C}$; (2) COM group: cells were incubated with crystals $(67 \mu \mathrm{g} / \mathrm{cm} 2$ of cells); (3) $\mathrm{COM}+\mathrm{GdCl} 3: \mathrm{GdCl} 3(300 \mu \mathrm{M})$ was added to growth medium for half an hour, and then crystals were added; (4) COM+NPS2390 group: After NPS2390 (10 $\mu \mathrm{M})$ was added to growth medium for 1 hour, the crystals were also added. After cells were treated with crystals for $6,12,24$, and 48 hours, the unbound crystals were removed and collected. They were counted in 5 randomized high-power fields (HPFs) under a phase contrast microscope. This experiment was carried out in triplicate.

\section{Statistical analysis}

Quantitative data are presented as the mean \pm SEM. All statistical analyses were performed using SPSS software version 13.0. ANOVA was used to analyse differences among multiple groups, and t tests were used to compare 2 groups. A 2-sided $p<0.05$ was considered to indicate statistical significance.

\section{Results}

\section{Proteomic analysis}

Approximately 900 protein spots were visualized in each 2-D gel by spot matching. Quantitative intensity analysis and statistical analysis showed that the expression levels of only 11 protein spots (10 defined proteins) in the high-COM exposure group were significantly changed by more than 1.5 times (including 9 upregulated proteins and 1 downregulated protein) (Fig 1). These changed protein spots were detected using ESI-MS/MS analysis. Table 1 summarizes the identified peptide numbers, protein scores, degrees of change (multiples) and other relevant information for all altered proteins (Table 1).

\section{PS exposure}

Since the fluorescent molecule Annexin V-FITC binds to PS when it appears on the cell surface, it can be used to detect the redistribution of PS. HK-2 cells were exposed to COM crystals ( $67 \mu \mathrm{g}$ of crystals $/ \mathrm{cm}^{2}$ of cells) for $24 \mathrm{~h}$, and PS exposure was assessed using flow cytometry. The percentage of Annexin V-FITC-positive cells was greater in the COM group than in the control group ( $p<$ 0.05). This finding indicates that PS exposure on the HK-2 cell membrane surface increased under the action of $\mathrm{COM} \mathrm{GdCl}_{3}$ further enhanced PS exposure, while NPS-2390 decreased it $(p<0.05)$, which suggests that CaSR helps to enhance PS exposure (Fig 2).

\section{Measurement of LDH, SOD, and MDA levels}


The LDH and MDA levels in the COM group were significantly higher than those in the control group, but the SOD levels were significantly lower $(p<0.05)$. The levels of $\mathrm{LDH}$ and MDA were elevated under $\mathrm{GdCl}_{3}$ treatment, while those of SOD were reduced ( $p$ $<0.01)$. However, NPS2390 reduced the concentrations of LDH and MDA and increased those of SOD $(p<0.05)$ (Fig 3).

\section{NBD-PS inward movement}

Fluorescent NBD-PS was used to label outer membrane leaflets to verify whether COM crystals affected the inward transport of PS from the outer membrane leaflet to the inner leaflet, and its internalization was monitored over time (Fig 4A). Approximately $90 \%$ of NBD-PS was internalized by HK-2 cells within $24 \mathrm{~h}$ (Fig 4B). However, under COM treatment ( $67 \mu \mathrm{g}$ of crystals/ $\mathrm{cm}^{2}$ of cells), the percentage of internalized NBD-PS decreased to 48\% (Fig 4B), which was lower than the control rate $(p<0.05)$. The inward transport rate of PS increased after the addition of the CaSR inhibitor NPS2390 to COM-treated cells $(p<0.05)$. Approximately $71 \%$ of NBD-PS

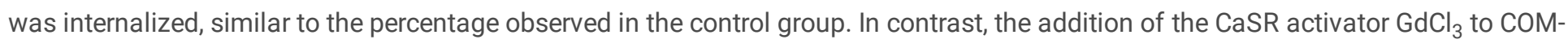
treated cells significantly inhibited the inward transport rate of PS $(p<0.05)$ (Fig 4B).

We also preincubated cells with the APLT inhibitor N-ethylmaleimide (NEM, Sigma-Aldrich) (5 mM) for 15 min and tested the inward movement of NBD-PS. After NEM treatment, the intrinsic kinetics became similar regardless of the presence or absence of other agents and decreased compared to the control values ( $p<0.05$, Fig 4B). These findings indicate that the inward movement of PS in HK-2 cells is mediated by APLT activity and that CaSR can modulate APLT activity in COM lesions.

\section{NBD-PS outward movement}

We also used NBD-PS to label cells intracellularly, and we determined the degree of movement of NBD-PS to the outer leaflet to investigate whether the outward transport of PS was affected by COM. The incubation medium contained BSA ( $1 \% \mathrm{w} / \mathrm{v})$, which can quickly extract NBD-PS expressed on the cell surface, thereby eliminating interference with APLT-mediated inward transport. In control cells, only approximately $20 \%$ of NBD-PS migrated to the outer leaflets within $24 \mathrm{~h}$ (Fig 5B), which may have been due to normal floppase activity. However, COM crystal treatment ( $67 \mu \mathrm{g}$ of crystals $/ \mathrm{cm}^{2}$ of cells) increased the PS outward transfer rate to $70 \%$, which was significantly greater than the rate in control cells $(\mathrm{p}<0.05)$. However, the addition of the CaSR activator $\mathrm{GdCl}_{3}$ or the $\mathrm{CaSR}$ inhibitor NPS2390 did not significantly affect this abnormal process, suggesting that the mechanism by which COM induces PS outward transport may not involve CaSR (Fig 5B).

\section{Western blot analysis}

CaSR was expressed in each group (Fig 6A). CaSR expression was clearly upregulated in the COM group (Fig 6A) compared with the control group. The expression of CaSR in the $\mathrm{COM}+\mathrm{GdCl}_{3}$ group was greater than that in the COM group (p<0.05) (Fig 6B).

Furthermore, CaSR expression was lower in the COM + NPS2390 group than in the COM group $(p<0.05)$ (Fig 6B). After COM treatment, APLT and SOD expression were downregulated, and NOX expression was upregulated $(p<0.05)$.

Upregulation of APLT and SOD expression and downregulation of NOX were observed in the COM + NPS2390 group compared with the COM group ( $p<0.05$ ). APLT and SOD expression were lower in the $\mathrm{COM}+\mathrm{GdCl}_{3}$ group than in the COM group. NOX expression, by contrast, was higher $(p<0.05)$ (Fig 6B).

We screened and examined the levels of caspase-dependent and caspase-independent apoptosis-related proteins in cells with or without NPS2390 and $\mathrm{GdCl}_{3}$. As shown in Fig 6D, COM stimulation significantly increased the expression of Bax, cleaved caspase-3, pro-caspase-8, cleaved caspase-8, caspase- 9 , cleaved caspase- 9 and cytochrome $\mathrm{C}$ proteins and reduced Bcl-2 expression. Compared with the COM group, this effect was reversed by NPS 2390 but enhanced by $\mathrm{GdCl}_{3}$. Therefore, $\mathrm{COM}$ stimulation affects the caspase cascade, and CaSR induces renal HK-2 apoptosis via the caspase-independent pathway.

\section{Crystal adherence to cells in groups}

The results showed that compared to the COM group, the CaSR activator significantly decreased the number of unbound crystals, which also means that the CaSR activator increased the number of adherent crystals (Figure 7$)(p<0.05)$. In contrast, the CaSR inhibitor resulted in a reduction in adherent crystals $(p<0.05)$. Crystal adherence to cells exposed to varying times $(6,12,24$, or 48 hours) was also determined in the four groups. The response was time-dependent (Figure 7). Figure 7 indicates that crystal adherence to HK-2 cells was the highest following 48 hours. 


\section{Discussion}

$\mathrm{COM}$ is critical in the formation of $\mathrm{CaOx}$ stones and impairs tubular epithelial cells[21, 22]. However, the understanding of the mechanism by which renal tubular cells respond to COM is still limited. Therefore, we performed a gel-based proteomics study to determine the protein changes that occur in renal tubular cells due to high COM exposure (Fig. 1 and Table 1). The induction of 10 proteins by $\mathrm{CaOx}$ crystals was detected by 2-DE of HK-2 cells. These altered proteins are involved in several cellular functions.

One of the differentially expressed proteins was CaSR. There is increasing evidence that CaSR may be involved in the formation of kidney stones[23-25]. In our previous study, we found that activation of CaSR by COM may lead to crystal retention and renal insufficiency[10]. However, the exact mechanism by which CaSR mediates crystal adhesion is not clear. Studies have shown that the appearance of extracellular PS in renal epithelial cells may promote the adhesion of COM crystals on the cell surface[26]. Therefore, we speculate that the appearance of extracellular PS in renal epithelial cells may be promoted by CaSR.

In our study, we observed increased CaSR expression, PS exposure, apoptosis, ROS production and crystal adhesion in HK-2 cells after treatment with COM. Moreover, the CaSR inhibitor NPS2390 reduced ROS production, PS exposure, apoptosis and crystal adhesion, while the CaSR activator $\mathrm{GdCl}_{3}$ significantly increased ROS production, PS exposure, apoptosis and crystal adhesion. To the best of our knowledge, we are the first to demonstrate that COM-induced PS exposure and apoptosis are mediated by CaSR. In addition, we observed enhanced outward movement of NBD-PS after COM treatment. However, changes in CaSR activity did not significantly affect the outward movement of NBD-PS, suggesting that the PS outward movement caused by the interaction of COM with membrane lipids is not mediated by CaSR.

In addition to increased outward movement, we observed impaired inward movement of NBD-PS in COM-treated HK-2 cells, which may be due to reduced APLT activity. This finding indicated that the cells were unable to rapidly transport the externalized PS back to the inner leaflets of their plasma membranes. The inhibition of APLT activity mediated by COM was accompanied by increased cellular CaSR production and was attenuated by treatment with the CaSR inhibitor NPS2390 (or enhanced by treatment with the CaSR activator $\mathrm{GdCl}_{3}$ ), implying that the COM-mediated decrease in APLT activity was dependent upon CaSR intermediates.

Injury to HK-2 cells, such as necrosis and apoptosis, is a common mechanism underlying the pathophysiology of urolithiasis[27]. HK-2 cell injury and apoptosis promote crystallization by providing substrates for heterogeneous crystal nucleation[28]. Cell degradation following HK-2 cell injury provides numerous membrane vesicles, which are good nucleators of crystals, promotes nucleation at low supersaturation, and enhances interactions between cells and crystals[29]. However, the detailed mechanisms by which COM promotes the apoptosis and necrosis of HK-2 cells are unknown. Many pro-apoptotic and anti-apoptotic proteins, such as Bcl-2, Bcl-xL, Bax and Bak, participate in the apoptosis process. Studies have narrowed the range of downstream factors to the caspase family. Ultimately, we selected caspase-8 and caspase-9 (the activated initiators of the apoptotic pathway) and caspase-3 (a key apoptotic protein). Western blotting was used to analyse the levels of these members of the caspase family, and we found that COM-induced apoptosis depends on caspase- $3,-8$ and -9 via activation of CaSR.

Studies have shown that oxalate-induced increased ROS generation impairs APLT activity and that decreased APLT activity has a role in hyperoxaluria-promoted $\mathrm{CaOx}$ stones by facilitating phosphatidylserine redistribution in kidney epithelial cells[30].

CaSR-mediated loss of APLT activity may be a key cause of COM-induced PS exposure in renal epithelial cells. In addition, disturbance of the physiochemical milieu may lead to ROS generation and OS development. ROS begin a signalling cascade culminating in the generation of macromolecules that suppress crystal nucleation, growth and aggregation. In the case of transitory disorder, either no crystal will take shape or the formed crystals will remain tiny and well dispersed and will be expelled as particles, causing crystalluria. Persistent disorders, such as hyperoxaluria, hyper-COM and hypocitraturia, are associated with imbalances between oxidative and antioxidative forces. ROS-induced cell damage leads to cell death and the formation of membrane-bound vesicles that support crystal adhesion[31, 32]. In our study, high COM exposure led to OS development mediated by CaSR. PS exposure, apoptosis and increased OS may eventually lead to crystal retention and kidney damage. We have thus provided a new theoretical basis for the mechanism of CaOx stone formation (Fig. 8).

\section{Conclusions}

Our study presents novel, direct evidence that COM-induced increases in CaSR increase OS production and impair APLT activity. This impairment of APLT activity results in PS externalization on the renal epithelial cell membrane and apoptosis of renal epithelial cells.

Page $7 / 17$ 
Since the negatively charged PS on the cell surface may serve as an anionic molecule to mediate COM crystal adhesion, the sequence of events suggested in this study might explain the mechanism of COM-induced $\mathrm{CaOx}$ stone disease. Decreasing CaSR activity can attenuate the aforementioned abnormalities, which partly demonstrates the mechanism underlying the protective effects of CaSR inhibitors against $\mathrm{CaOx}$ adhesion and retention on the renal epithelial cell surface.

\section{Abbreviations}

COM, calcium oxalate monohydrate;HK-2,Human Kidney-2; CaSR, calcium-sensing receptor; PS, phosphatidylserine; ROS, reactive oxygen species; APLT, aminophospholipid translocase; MDA, malondialdehyde; OS, oxidative stress; CaOx, calcium oxalate; SOD, superoxide dismutase; LDH, lactate dehydrogenase

\section{Declarations}

\section{Ethics approval and consent to participate}

Not applicable.

\section{Consent for publication}

Not applicable.

\section{Availability of data and materials}

The data used to support the findings of this study are available from the corresponding author upon reasonable request.

\section{Competing interests}

The authors declare that they have no competing interests.

\section{Funding}

The present study was supported by the National Natural Science Foundation of China (No. 81700614). This study was supported by the Cuiying Scientific and Technological Innovation Program of Lanzhou University Second Hospital (Grant number CY2017-QN01). This study was also supported by the Fundamental Research Funds for the Central Universities.

\section{Contributions}

Conceived and designed the study: Xiaoran Li and Siyu Chen. Analysis and interpretation of some data: Siyu Chen, Junsheng Bao and Xiaoran Li. Performed the studies: Siyu Chen, Junsheng Bao, Jianzhong Lu and Zhongyun Ning. Contributed reagents/materials/analysis tools: Zhongjin Yue and Xiaoran Li. Wrote the manuscript: Siyu Chen and Xiaoran Li. All authors read and approved the final manuscript.

\section{Acknowledgements}

The authors wish to thank the Shanghai Applied Protein Technology Co., Ltd for technical assistance.

\section{Authors' information}

*Corresponding author: Xiaoran Li, Institute of Urology, Gansu Nephro-Urological Clinical Center, Department of Urology Mailing address: Second Hospital of Lanzhou University, 82 Cui Ying Men, Lanzhou 730030, Gansu, China.

E-mail: lixiaoran05@163.com. Fax: +869318942296. Telephone: +8613919012874.

\section{References}

1. Bamberger JN, et al. Clinical and Metabolic Correlates of Calcium Oxalate Stone Subtypes: Implications for Etiology and Management. J Endourol. 2019;33(9):755-60. 
2. Wang B, et al., miRNA-34a inhibits cell adhesion by targeting CD44 in human renal epithelial cells: implications for renal stone disease. Urolithiasis, 2019.

3. Zhu W, et al., The Protective Roles of Estrogen Receptor beta in Renal Calcium Oxalate Crystal Formation via Reducing the Liver Oxalate Biosynthesis and Renal Oxidative Stress-Mediated Cell Injury. Oxid Med Cell Longev, 2019. 2019: p. 5305014.

4. Manissorn J, et al. Systematic evaluation for effects of urine $\mathrm{pH}$ on calcium oxalate crystallization, crystal-cell adhesion and internalization into renal tubular cells. Sci Rep. 2017;7(1):1798.

5. Cao LC, et al. Oxalate-induced redistribution of phosphatidylserine in renal epithelial cells: implications for kidney stone disease. Am J Nephrol. 2001;21(1):69-77.

6. Wiessner $\mathrm{JH}$, et al. Oxalate-induced exposure of phosphatidylserine on the surface of renal epithelial cells in culture. J Am Soc Nephrol. 1999;10 Suppl 14:S441-5.

7. Schroit AJ, Zwaal RF. Transbilayer movement of phospholipids in red cell and platelet membranes. Biochim Biophys Acta. 1991;1071(3):313-29.

8. Devaux PF, Lopez-Montero I, Bryde S. Proteins involved in lipid translocation in eukaryotic cells. Chem Phys Lipids. 2006;141(12):119-32.

9. Zwaal RF, Comfurius P, Bevers EM. Surface exposure of phosphatidylserine in pathological cells. Cell Mol Life Sci. 2005;62(9):971-88.

10. Li X, et al., Calcium Oxalate Induces Renal Injury through Calcium-Sensing Receptor. Oxid Med Cell Longev, 2016. 2016: p. 5203801.

11. Segawa K, Nagata S. An Apoptotic 'Eat Me' Signal: Phosphatidylserine Exposure. Trends Cell Biol. 2015;25(11):639-50.

12. Shlomovitz I, Speir M, Gerlic M. Flipping the dogma - phosphatidylserine in non-apoptotic cell death. Cell Commun Signal. 2019;17(1):139.

13. Khan SR, Khan A, Byer KJ. Temporal changes in the expression of mRNA of NADPH oxidase subunits in renal epithelial cells exposed to oxalate or calcium oxalate crystals. Nephrol Dial Transplant. 2011;26(6):1778-85.

14. Zuo J, et al. Effect of NADPH oxidase inhibition on the expression of kidney injury molecule and calcium oxalate crystal deposition in hydroxy-L-proline-induced hyperoxaluria in the male Sprague-Dawley rats. Nephrol Dial Transplant. 2011;26(6):1785-96.

15. Byer K, Khan SR. Citrate provides protection against oxalate and calcium oxalate crystal induced oxidative damage to renal epithelium. J Urol. 2005;173(2):640-6.

16. Thamilselvan $S$, et al. Free radical scavengers, catalase and superoxide dismutase provide protection from oxalate-associated injury to LLC-PK1 and MDCK cells. J Urol. 2000;164(1):224-9.

17. Chen $\mathrm{S}$, et al. Analysis of HK-2 cells exposed to oxalate and calcium oxalate crystals: proteomic insights into the molecular mechanisms of renal injury and stone formation. Urol Res. 2010;38(1):7-15.

18. McIntyre JC, Sleight RG. Fluorescence assay for phospholipid membrane asymmetry. Biochemistry. 1991;30(51):11819-27.

19. Pohl A, et al. Transport of phosphatidylserine via MDR1 (multidrug resistance 1)P-glycoprotein in a human gastric carcinoma cell line. Biochem J. 2002;365(Pt 1):259-68.

20. Kanlaya R, Fong-Ngern K, Thongboonkerd V. Cellular adaptive response of distal renal tubular cells to high-oxalate environment highlights surface alpha-enolase as the enhancer of calcium oxalate monohydrate crystal adhesion. J Proteomics. 2013;80:5565.

21. Peerapen $P$, Thongboonkerd V. Effects of calcium oxalate monohydrate crystals on expression and function of tight junction of renal tubular epithelial cells. Lab Invest. 2011;91(1):97-105.

22. Worcester EM, et al. Evidence that postprandial reduction of renal calcium reabsorption mediates hypercalciuria of patients with calcium nephrolithiasis. Am J Physiol Renal Physiol. 2007;292(1):F66-75.

23. Vezzoli G, et al. Risk of nephrolithiasis in primary hyperparathyroidism is associated with two polymorphisms of the calciumsensing receptor gene. J Nephrol. 2015;28(1):67-72.

24. Besiroglu $\mathrm{H}$, et al. Calcium-sensing receptor gene polymorphisms in patients with calcium urolithiasis: a systematic review. Ren Fail. 2014;36(8):1187-92.

25. Walker RW, et al. Calcium receptor signaling and citrate transport. Urolithiasis. 2018;46(5):409-18. 
26. Bigelow MW, et al. Surface exposure of phosphatidylserine increases calcium oxalate crystal attachment to IMCD cells. Am J Physiol. 1997;272(1 Pt 2):F55-62.

27. Tsujihata M. Mechanism of calcium oxalate renal stone formation and renal tubular cell injury. Int J Urol. 2008;15(2):115-20.

28. Mulay SR, et al. Cytotoxicity of crystals involves RIPK3-MLKL-mediated necroptosis. Nat Commun. 2016;7:10274.

29. Fasano JM, Khan SR. Intratubular crystallization of calcium oxalate in the presence of membrane vesicles: an in vitro study. Kidney Int. 2001;59(1):169-78.

30. Yu SL, et al. Oxalate impairs aminophospholipid translocase activity in renal epithelial cells via oxidative stress: implications for calcium oxalate urolithiasis. J Urol. 2011;186(3):1114-20.

31. Khan SR, et al. Presence of lipids in urine, crystals and stones: implications for the formation of kidney stones. Kidney Int. 2002;62(6):2062-72.

32. Talham DR, et al. Role of lipids in urinary stones: studies of calcium oxalate precipitation at phospholipid langmuir monolayers. Langmuir. 2006;22(6):2450-6.

\section{Tables}

Table 1 Summary of significantly altered proteins in HK-2 cells in response to high COM exposure

\begin{tabular}{|c|c|c|c|c|c|c|c|c|c|c|}
\hline $\begin{array}{l}\text { Spot } \\
\text { no. }\end{array}$ & Protein & NCBI entry & $\begin{array}{l}\text { Protein } \\
\text { MW }\end{array}$ & $\begin{array}{l}\text { Protein } \\
\mathrm{Pl}\end{array}$ & $\begin{array}{l}\text { No. of } \\
\text { identified } \\
\text { peptides }\end{array}$ & $\begin{array}{l}\text { Protein } \\
\text { Score }\end{array}$ & $\begin{array}{l}\text { Protein } \\
\text { Score } \\
\text { C. I. \% }\end{array}$ & $\begin{array}{l}\text { Intensity } \\
\text { Matched }\end{array}$ & $\begin{array}{l}\text { Total } \\
\text { lon } \\
\text { Score }\end{array}$ & $\begin{array}{l}\text { Degree } \\
\text { of } \\
\text { change } \\
\text { (fold) }\end{array}$ \\
\hline 1980 & $\begin{array}{l}\text { hydroxyacyl- } \\
\text { Coenzyme A } \\
\text { dehydrogenase, } \\
\text { type II, isoform } \\
\text { CRA_b }\end{array}$ & gi|119613564 & 26195.7 & 6.73 & 5 & 248 & 100 & 10.737 & 226 & 3.01400 \\
\hline 1398 & $\begin{array}{l}\text { annexin A2 } \\
\text { isoform } 2\end{array}$ & gi|50845386 & 38807.9 & 7.57 & 20 & 352 & 100 & 19.852 & 246 & 2.19216 \\
\hline 1406 & $\begin{array}{l}\text { calcium- } \\
\text { sensing } \\
\text { receptor }\end{array}$ & gi|408359999 & 12918.1 & 6.57 & 10 & 200 & 100 & 12.257 & 176 & 1.73504 \\
\hline 607 & $\begin{array}{l}\text { lamin isoform } \\
\mathrm{C}\end{array}$ & gil5031875 & 65152.6 & 6.4 & 23 & 99 & 99.995 & 5.5 & 20 & 1.63278 \\
\hline 1300 & $\begin{array}{l}\text { annexin A2, } \\
\text { isoform CRA_a }\end{array}$ & gi|119597988 & 40670.8 & 8.53 & 22 & 1,000 & 100 & 55.577 & 873 & 1.59897 \\
\hline 1916 & peroxiredoxin-1 & gi|32455266 & 22324.4 & 8.27 & 15 & 313 & 100 & 15.829 & 199 & -1.58798 \\
\hline 1586 & $\begin{array}{l}\text { proteasome } \\
\text { subunit alpha } \\
\text { type-1 isoform } \\
3\end{array}$ & gi|221316716 & 14728.6 & 8.69 & 8 & 220 & 100 & 10.177 & 168 & 1.57837 \\
\hline 1744 & $\begin{array}{l}\text { actin, } \\
\text { cytoplasmic } 2\end{array}$ & gi|54036678 & 42107.9 & 5.31 & 10 & 321 & 100 & 19.782 & 278 & 1.54370 \\
\hline 1331 & $\begin{array}{l}\text { actin, } \\
\text { cytoplasmic } 2\end{array}$ & gi|316659409 & 42107.9 & 5.31 & 10 & 584 & 100 & 25.528 & 543 & 1.51170 \\
\hline 1717 & $\begin{array}{l}\text { electron } \\
\text { transfer } \\
\text { flavoprotein } \\
\text { subunit beta } \\
\text { isoform } 2\end{array}$ & gi|62420877 & 37753.1 & 6.78 & 10 & 314 & 100 & 13.045 & 273 & 1.51036 \\
\hline
\end{tabular}




\section{Figures}

\section{$3 \longleftrightarrow \mathrm{PI} \longrightarrow 103 \longleftrightarrow$ $3 \longrightarrow$}
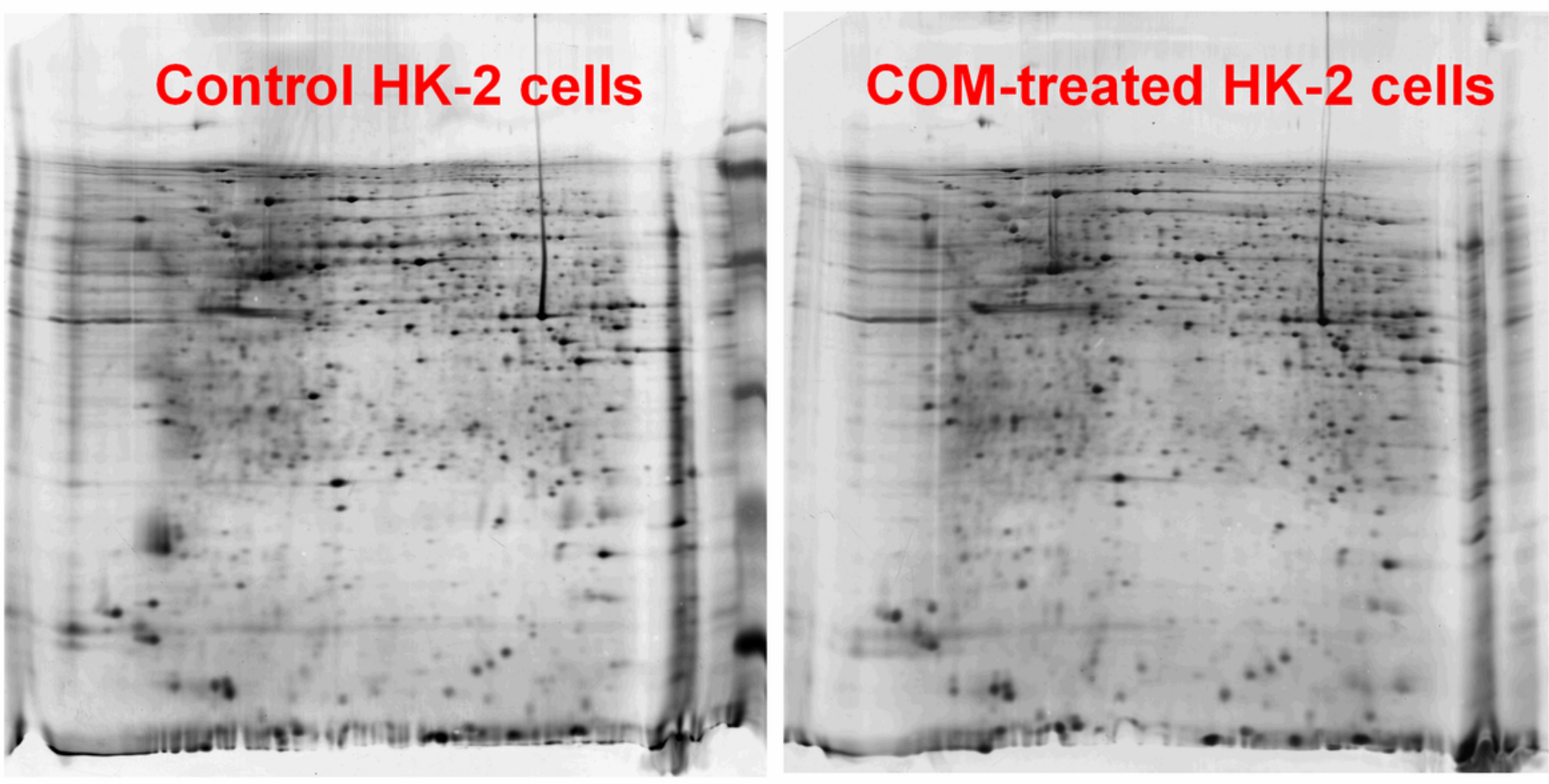

\section{Figure 1}

2-DE maps of proteins from COM-treated HK-2 cells and control HK-2 cells. Confluent HK-2 cells were exposed to COM crystals $(67 \mu \mathrm{g}$ of crystals/cm2 of cells) for $24 \mathrm{~h}$. HK-2 cells without COM crystals were used as controls. At the end of the experimental period, the cells were washed and harvested. The cell suspensions were subsequently sonicated for protein extraction. The gels were stained with silver diamine. 


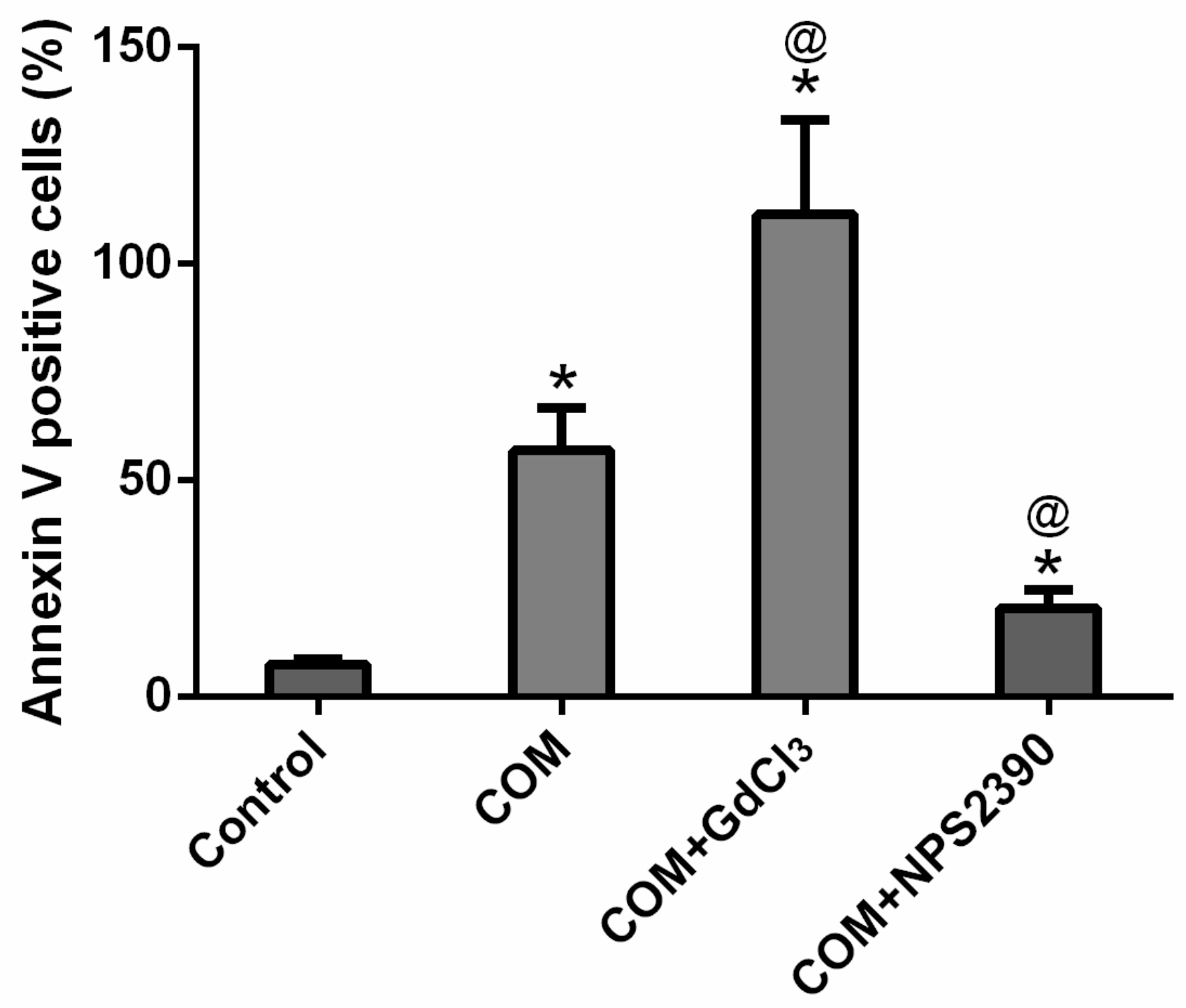

Figure 2

COM-induced PS exposure in HK-2 cells. The percentages of PS-externalized cells are shown. (1) Control group: HK-2 cells were continuously cultured at $37^{\circ} \mathrm{C}$ for $24 \mathrm{~h}$ in DMEM. (2) COM group: HK-2 cells were incubated with COM ( $67 \mu \mathrm{g}$ of crystals/cm2 of cells) at $37^{\circ} \mathrm{C}$ for $24 \mathrm{~h}$. (3) $\mathrm{COM}+\mathrm{GdCl} 3$ group: HK-2 cells were pretreated with the CaSR activator $\mathrm{GdCl} 3(300 \mu \mathrm{M})$ for 30 min; COM crystals were then added to the growth medium ( $67 \mu \mathrm{g}$ of crystals/ $\mathrm{cm} 2$ of cells), and the cells were incubated at $37^{\circ} \mathrm{C}$ for $24 \mathrm{~h}$. (4) COM+NPS2390 group: HK-2 cells were pretreated with the CaSR inhibitor NPS2390 (10 $\mu \mathrm{M})$ for $60 \mathrm{~min}$; COM crystals were then added to the growth medium ( $67 \mu \mathrm{g}$ of crystals/cm2 of cells), and the cells were incubated at $37^{\circ} \mathrm{C}$ for $24 \mathrm{~h}$. ${ }^{\star} \mathrm{p}<0.05 \mathrm{vs}$ the control group. @p $<0.05$ vs the COM group. 
A

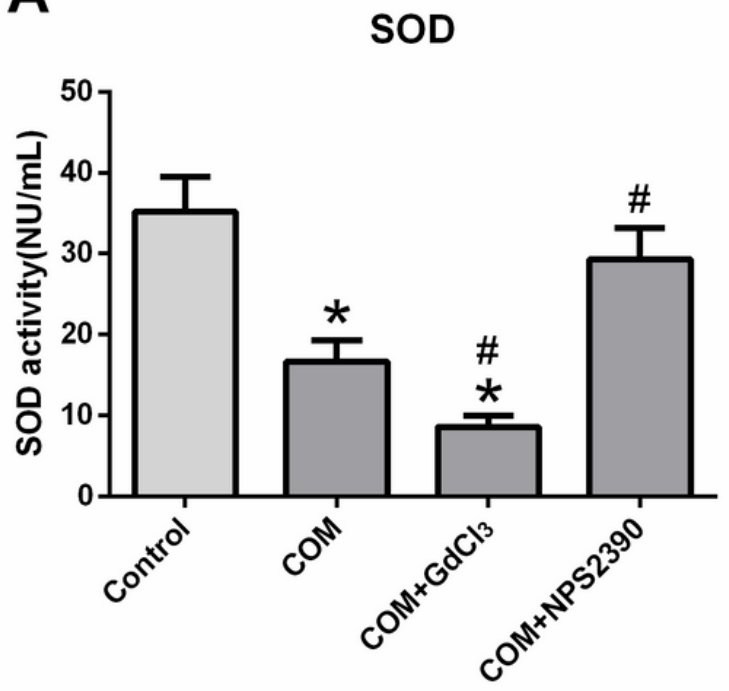

B

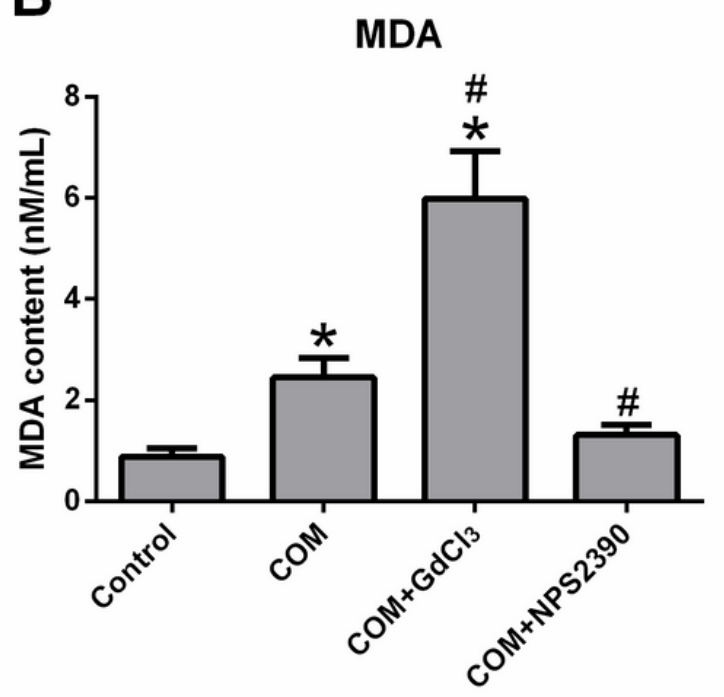

C

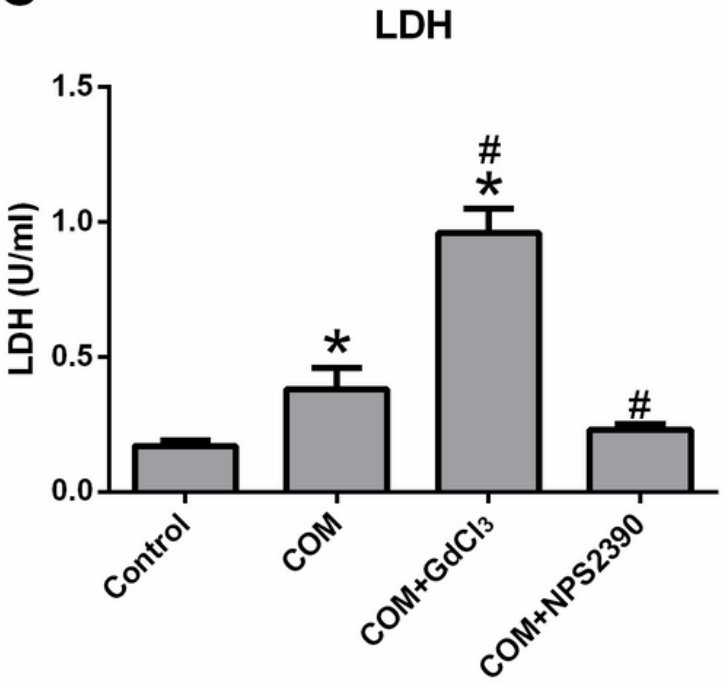

Figure 3

Levels of SOD activity, MDA in cells and LDH in culture medium for the different groups. ${ }^{\star} p<0.05$ vs the control group. \#p<0.05 vs the COM group. 


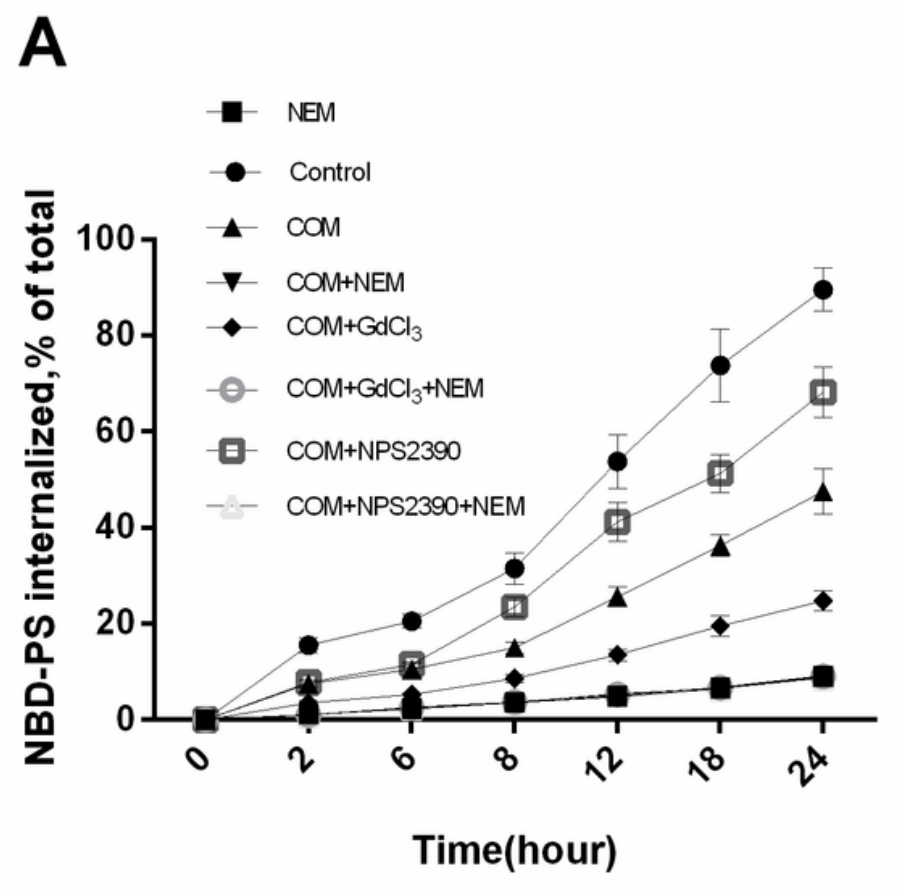

B

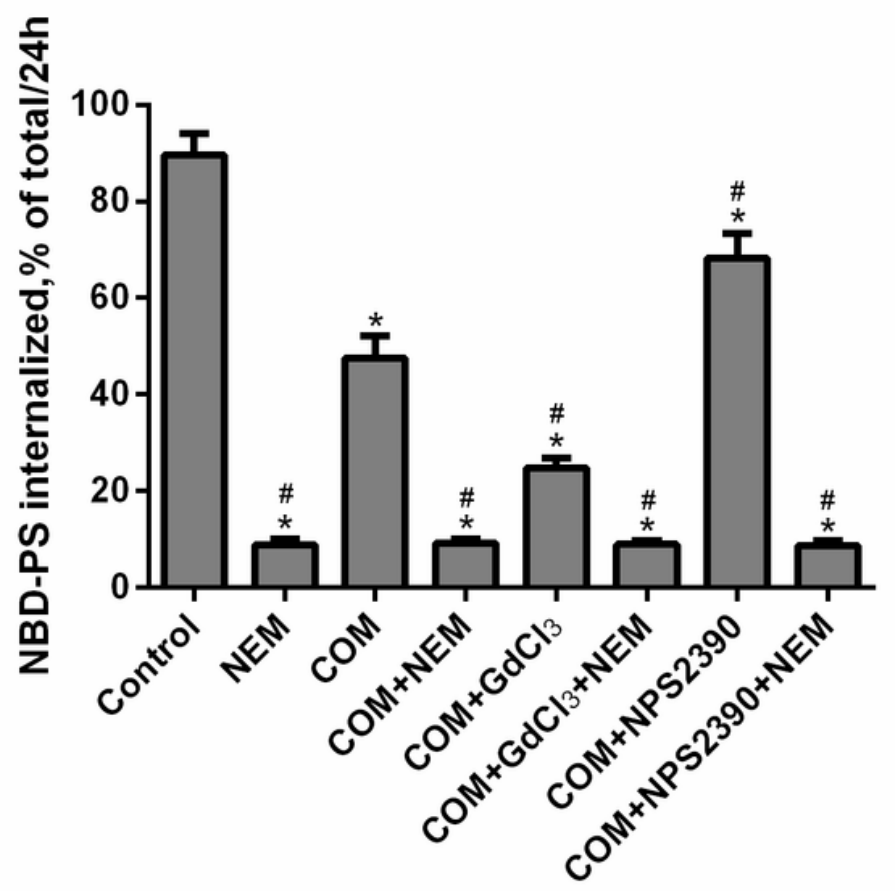

Figure 4

NBD-PS internalization in HK-2 cells incubated with COM in the presence of the CaSR activator GdCl3 $(300 \mu \mathrm{M})$ for 30 min or the CaSR inhibitor NPS2390 $(10 \mu \mathrm{M})$ for 60 min. A, time course. B, rate. ${ }^{\star} p<0.05$ vs the control group without NEM. \# $p<0.05$ vs the COM group.

A

B
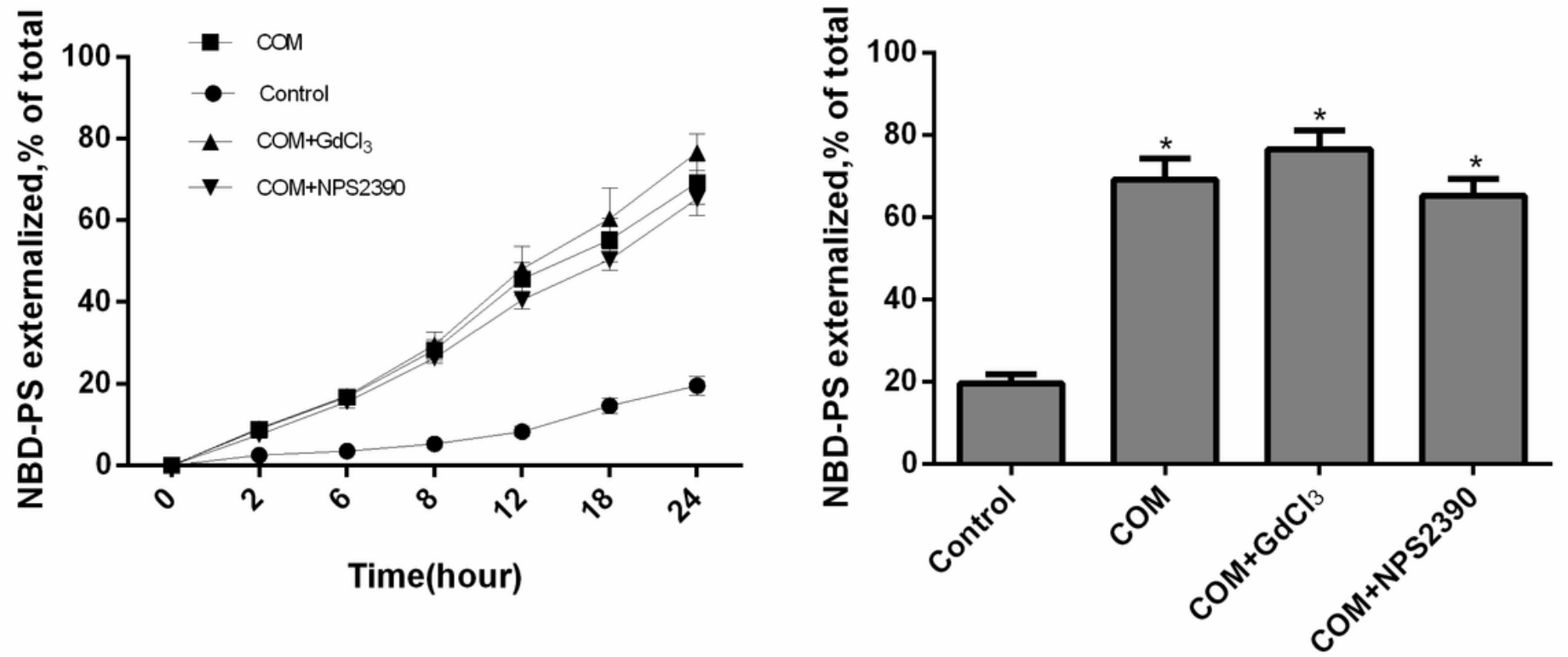

Figure 5 


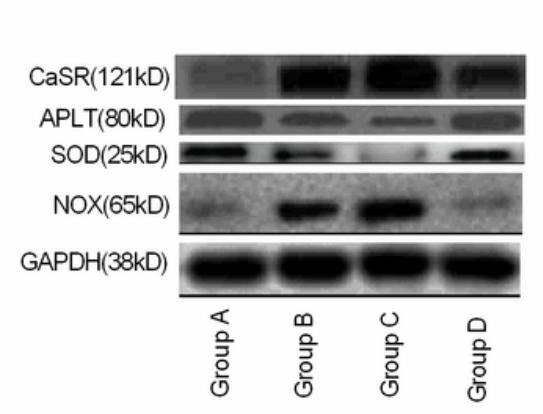

A

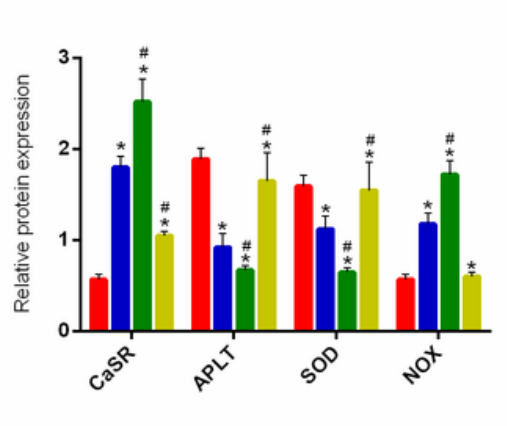

B

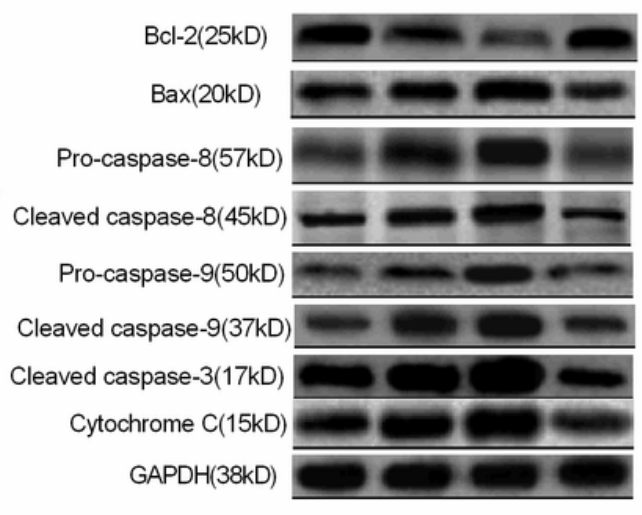

C

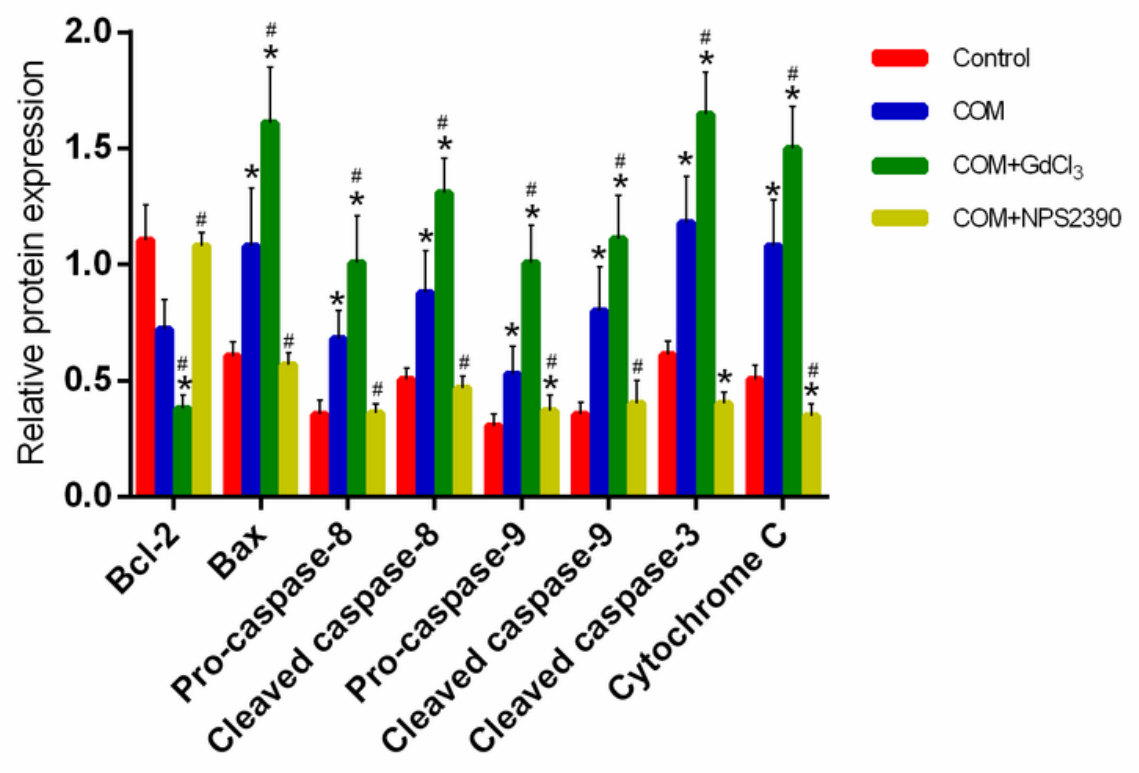

Figure 6

COM induces HK-2 injury through CaSR and subsequent APLT, ROS and caspase-dependent pathways. A and B: Levels of CaSR, APLT and ROS. C and D: Protein levels of Bcl-2, Bax, pro-caspase-9, caspase-9, pro-caspase-8, cleaved caspase-8, cleaved caspase-3, and cytochrome $\mathrm{C}$ in different groups of HK-2 cells as determined by Western blotting. The data are expressed as the mean \pm SEM. @ $<<0.05$ vs the control group. \#p $<0.05$ vs the COM group. 

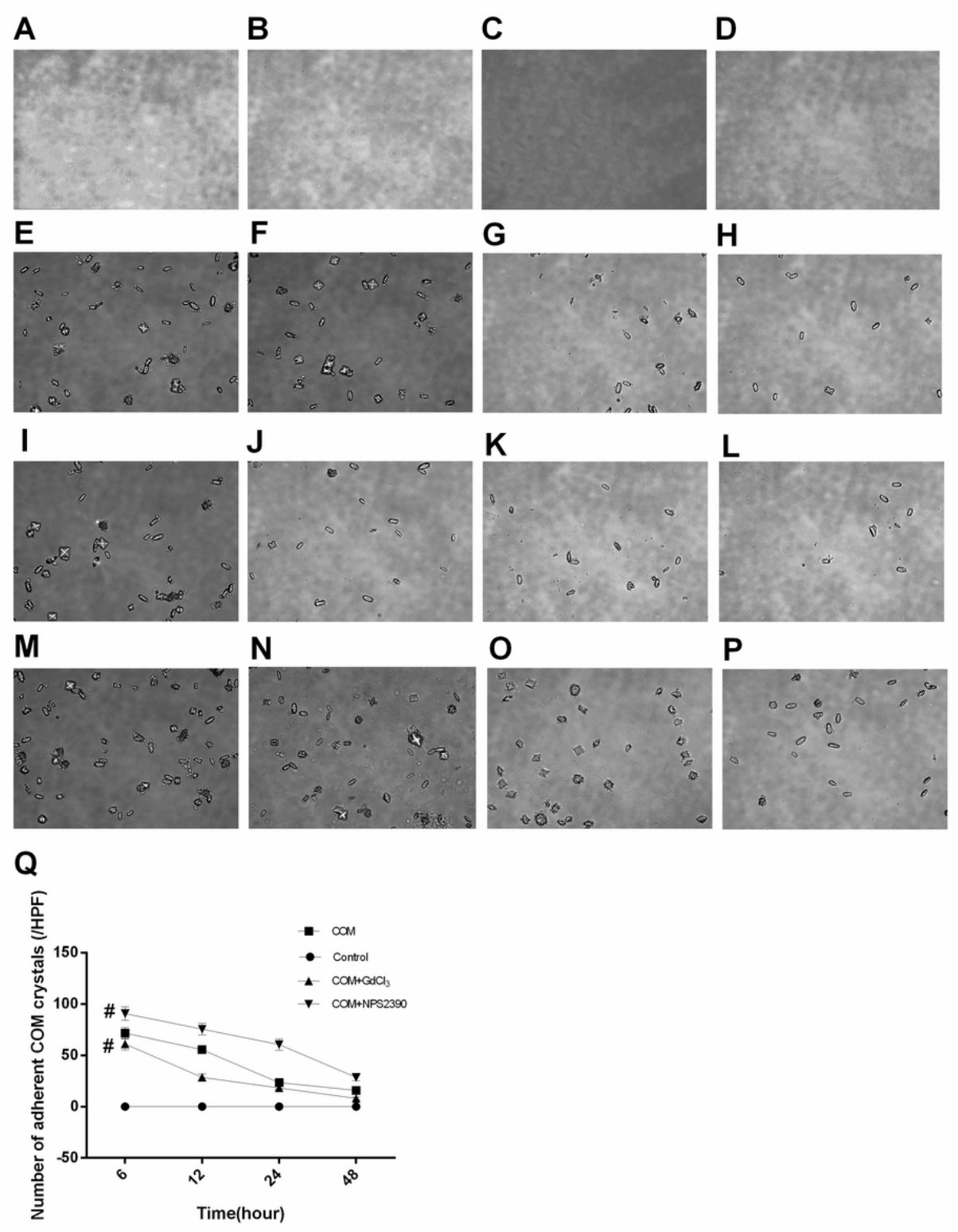

\section{Figure 7}

COM crystal adhesion assay. Unbound crystals under microscopy on hours 6, 12, 24 and 48 in the 4 groups. No crystals were observed at 6 hours (A), 12 hours (B), 24 hours (C) or 48 hours (D) in the control group. Unbound crystals were observed at 6 hours (E), 12 hours (F), 24 hours (G) or 48 hours $(H)$ in the COM group. However, few depositions were found at 6 hours (I), 12 hours (G), 24 hours (K) or 48 hours $(\mathrm{L})$ in the $\mathrm{COM}+\mathrm{GdCl} 3$ group compared to the COM group. The unbound crystals were significantly increased at 6 hours $(M), 12$ hours $(N), 24$ hours $(0)$ or 48 hours $(P)$ in the COM+NPS2390 group compared to the COM group. (Q): Number of crystals in groups. The data are expressed as the mean \pm SEM. $\# p<0.05$ vs the COM group. 

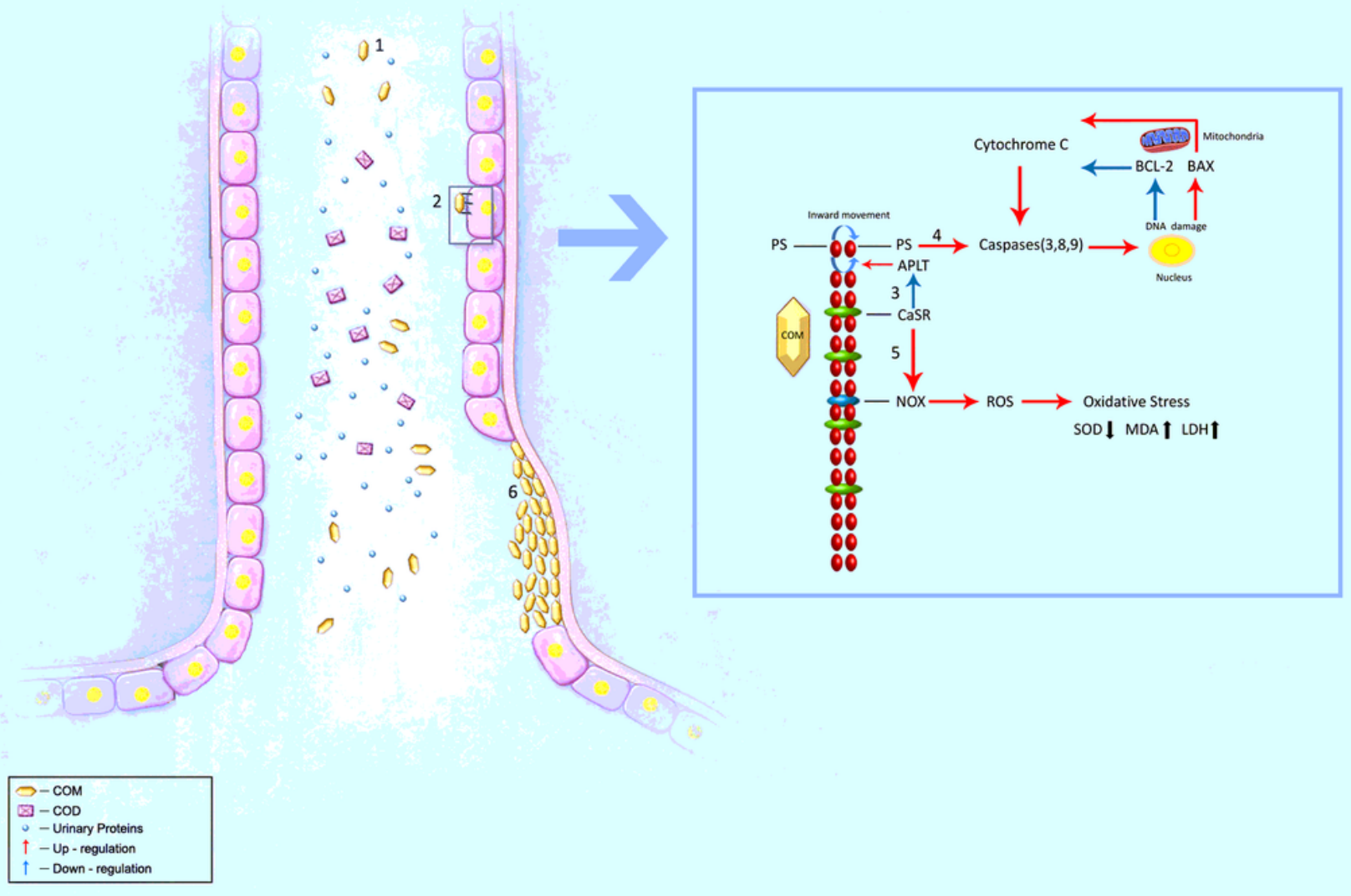

\section{Figure 8}

Roles of the CaSR protein in stone formation. (1) Oversaturation of calcium salts leads to the formation of crystals in the nephron lumen. (2) COM crystals adhere to renal epithelial cells, activating the CaSR protein. (3) COM-induced increases in CaSR impair APLT activity. Impairment of APLT activity could not effectively promote the inward movement of PS, resulting in externalization of PS on the renal epithelial cell membrane. Relocation of membrane lipids promotes the adherence of COM crystals. (4) PS externalization promotes cellular apoptosis. One well-known apoptotic mechanism acts via activation of caspase-9, which in turn activates other caspases (3 and 8). Activation of these caspases results in DNA damage. Activation of caspases requires an influx of cytochrome $\mathrm{C}$ into the cytosol from mitochondria. Bcl-2 family genes, such as Bcl-2 and Bax, control the release of cytochrome C. (5) High expression of the CaSR protein results in activation of plasma membrane NADPH oxidase (NOX), which increases ROS and OS production. (6) Renal epithelial cell injury causes loss of cellular adhesion, impairment of tight junction integrity, and exposure of the basement membrane. COM crystals are transported and deposited in the basement membrane, and the growth of basement membrane crystals may promote their nucleation. 